SAND- $-87-8210$

DE87 010028

SAND87-8210

Unlimited Release

Printed Apri1 1987
1986 ENVIRONMENTAL MONITORING REPORT

SANDIA NATIONAL LABORATORIES

LIVERMORE, CALIFORNIA

Thomas K. Devi in Hazards Control Division

Sandia National Laboratories, Livermore

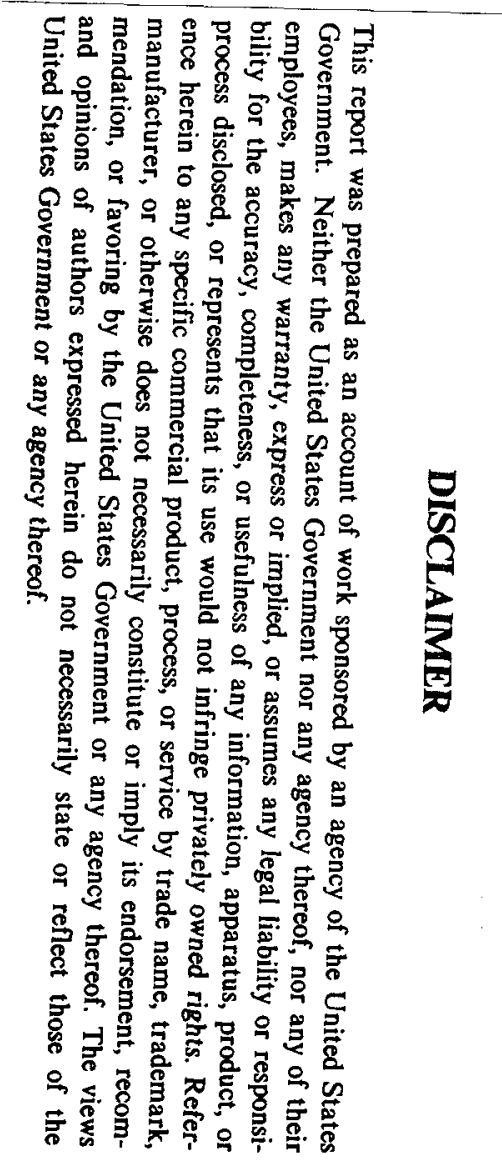

This document is

PURLICLERLEASABLE
BSluel
Authorizing Official
Date: i. 12410.6

ABSTRACT

Sandia National Laboratories at Livermore, California, is located $65 \mathrm{~km}$ ( 50 miles) southeast of San Francisco midway between the Pacific Ocean and the San Joaquin Valley. Sandia conducts various research activities related to Department of Energy interests which have the potential for release of hazardous materials or radionuclides to the environment. A strict environmental control program places maximum emphasis on limiting releases. The environmental monitoring program conducted by Lawrence Livermore National Laboratory and augmented by Sandia is designed to measure the performance of the environmental controls. The program includes analysis of air, water, soil, vegetation, sewer effluent, ground water, and foodstuffs for various toxic, hazardous, or radioactive materials. Based on these studies, the releases of materials of concern at Sandia during 1986 were well below applicable Department of Energy standards.

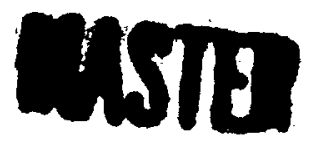




\section{DISCLAIMER}

This report was prepared as an account of work sponsored by an agency of the United States Government. Neither the United States Government nor any agency Thereof, nor any of their employees, makes any warranty, express or implied, or assumes any legal liability or responsibility for the accuracy, completeness, or usefulness of any information, apparatus, product, or process disclosed, or represents that its use would not infringe privately owned rights. Reference herein to any specific commercial product, process, or service by trade name, trademark, manufacturer, or otherwise does not necessarily constitute or imply its endorsement, recommendation, or favoring by the United States Government or any agency thereof. The views and opinions of authors expressed herein do not necessarily state or reflect those of the United States Government or any agency thereof. 


\section{DISCLAIMER}

Portions of this document may be illegible in electronic image products. Images are produced from the best available original document. 


\section{FOREMORD}

This report is prepared for the Department of Energy by the Hazards Control Division of Sandia National Laboratories (SNLL) at Livermore, California. Most of the data and analysis has been compiled by Lawrence Livermore National Laboratory (LLNL). The LLNL data has been summarized and augmented as appropriate to fulfill SNLL environmental monitoring and reporting requirements. In addition to the author, the following Sandia personnel made significant contributions to this report: R. S. Hafner, W. M. Rego, D. B. Ross, K. F. Siegfriedt, and D. A. Wright. W. V. Ormond II I has provided overall program guidance and critical review of this document. 


\section{CONTENTS}

Abbreviations

PAGE

Introduction

Summary - Environmental Control Program 9

$\begin{array}{ll}\text { Environmental Monitoring Program } & 10\end{array}$

Atmospheric Pollution 10

Soil $\quad 12$

Sewer Effluent 13

Water Pollution $\quad 14$

Vegetation and Foodstuffs 17

$\begin{array}{ll}\text { Thermoluminescent Dosimetry } & 17\end{array}$

Surface Water Runoff 18

Solid Waste 19

Quality Assurance $\quad 1.9$

$\begin{array}{ll}\text { References } & 20\end{array}$

\section{FIGURES}

1 Regional Setting of SNLL 6

2 Piezometric Surface - April 1985

3 Fuel Spill Evaluation - Location of Wells and Boreholes 16

\section{TABLES}

1 Gross Alpha Activity in Air 10

2 Gross Beta Activity in Air 10

3 Uranium-238 Concentration in Air 11

4 Beryllium Concentration in Air. 11

5 Tritium (HTO) Activity in Air 12

6 Uranium-238 in Soil 12

7 Tritium (HTO) in Sewage. 13

8 Physical and Chemical studies of SNLL liquid Effluent 14

9 Gross Alpha Activity in Livermore Valley Water 15

10 Gross Beta Activity in Livermore Valley Water 15

11 Tritium (HTO) in Livermore Valley Water 15

12. Tritium (HTO) in Vegetation and Foodstuffs 17

13 Environmental Radiation Measurements at Livermore Site 18

14 Storm Water Runoff 18

APPENDIX A. SUMMARY OF DISCHARGE LIMITS

CITY OF LIVERMORE WATER RECLAMATION PLANT 20 


\section{ABBREVIATIONS}

\section{Acronyms}

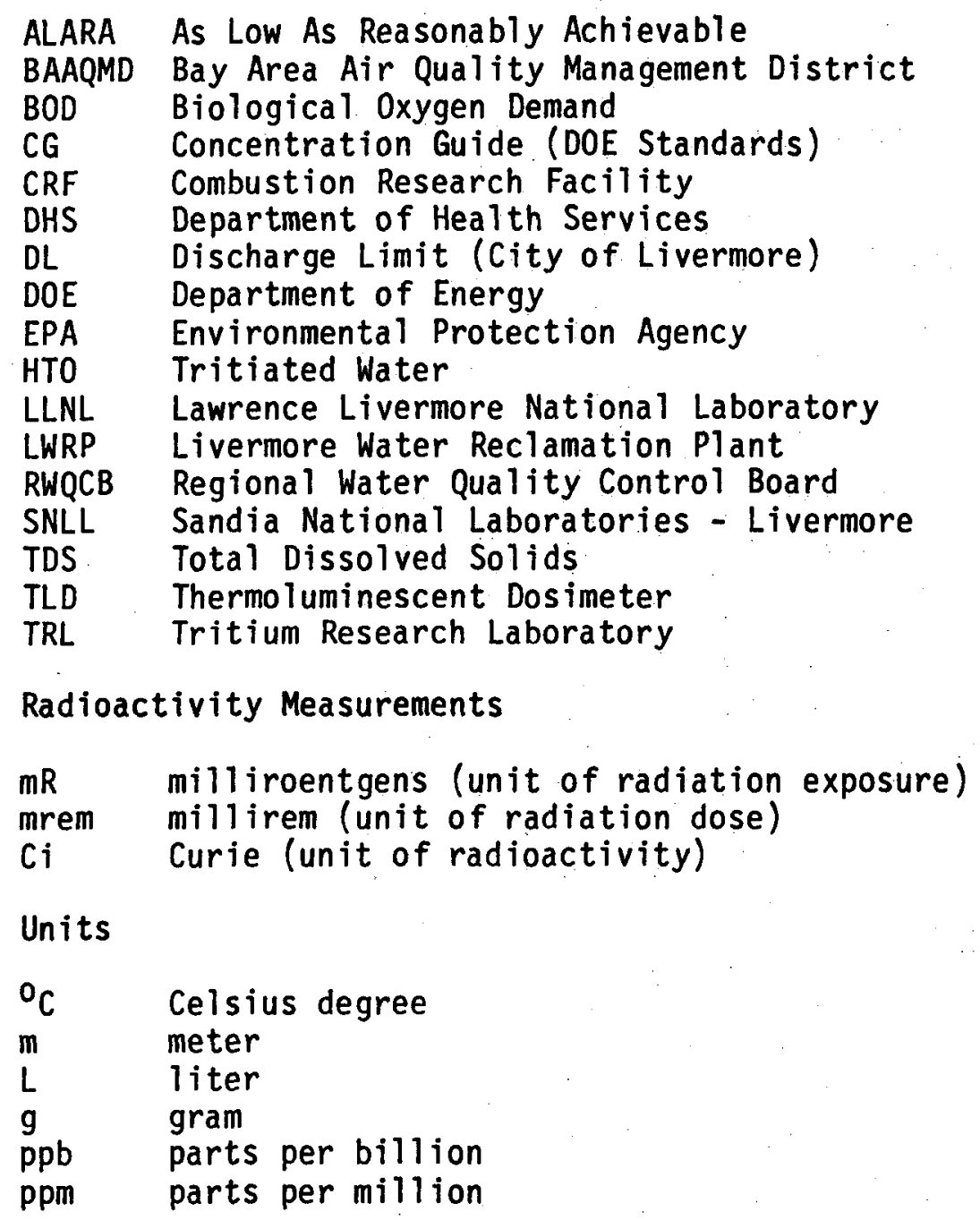

$\begin{array}{lll}10^{6} & \text { mega } & M \\ 10^{3} & \text { kilo } & \mathrm{k} \\ 10^{-3} & \text { milli } & \mathrm{m} \\ 10^{-6} & \text { micro } & \mathrm{u} \\ 10^{-9} & \text { nano } & \mathrm{n} \\ 10^{-12} & \text { pico } & \mathrm{p}\end{array}$




\title{
1986 ENVIRONMENTAL MONITORING REPORT
}

\author{
SAMDIA MATIONAL LABORATORIES
}

LIVERMORE, CALIFORMIA

\begin{abstract}
INTRODUCTION
Sandia National Laboratories at Livermore (SNLL) is a prime contractor to the Department of Energy (DOE) operated under provision of a non-profit, no fee contract with AT\&T Technologies Inc. SNLL employs approximately 1100 people. The site is immediately adjacent to the Lawrence Livermore National Laboratory (LLNL) which maintains a complete environmental monitoring program (Reference 1). SNLL augments the LLNL program by conducting additional monitoring and analysis to provide data specific to its operations. This report fulfills the requirement for environmental monitoring specified in DOE Order 5484.1.

SNLL is located $65 \mathrm{~km}$ ( 50 miles) southeast of San Francisco in the Central California Coastal Range Province along the southeastern portion of the Livermore Valley midway between the Pacific Ocean and the San Joaquin Valley (Figure 1). The SNLL site is situated on $0.89 \mathrm{~km}^{2}(221$ acres) of land located approximately $5 \mathrm{~km}$ ( 3 miles) east of the City of Livermore.

The Livermore Valley forms an irregularly shaped lowland area which slopes generally to the west at about 10 meters $/ \mathrm{km}$ ( 20 feet $/ \mathrm{mile}$ ). The intermittent streams that flow into the valley drain to the southwest with outflow near Sunol into the San Francisco Bay through Alameda Creek. The Livermore Valley overlies a complex geologic region where ancient arroyos have deposited a heterogeneous combination of sand, silts, clays, and gravels. These alluvial deposits occur in interfingering lenses of higher and lower permeability overlying the older Livermore formation. The ground water of the Livermore Valley occurs in the more permeable deposits at 5 to 32 meters (17 to 100 feet) below the SNLL site with a northwesterly flow as depicted in Figure 2 (from Reference 2). Ground water flow is influenced by the Las Positas Fault which is believed to provide significant resistance to westerly movement in the upper saturated zone.

Climate in the valley is typically warm and dry with an average rainfall of 36 $\mathrm{cm}$ (14 inches) occurring during the winter months. Prevailing winds are from the west and southwest during April through September. The remainder of the year is characterized by variable winds. Rainfall, as well as wind patterns, exhibit a strong seasonal pattern.

SNLL has assigned the Hazards Control Division the responsibility to assure that operations are conducted with the highest regard for the safety and health of personnel and the public, the protection and preservation of the environment, and the protection of government property.
\end{abstract}




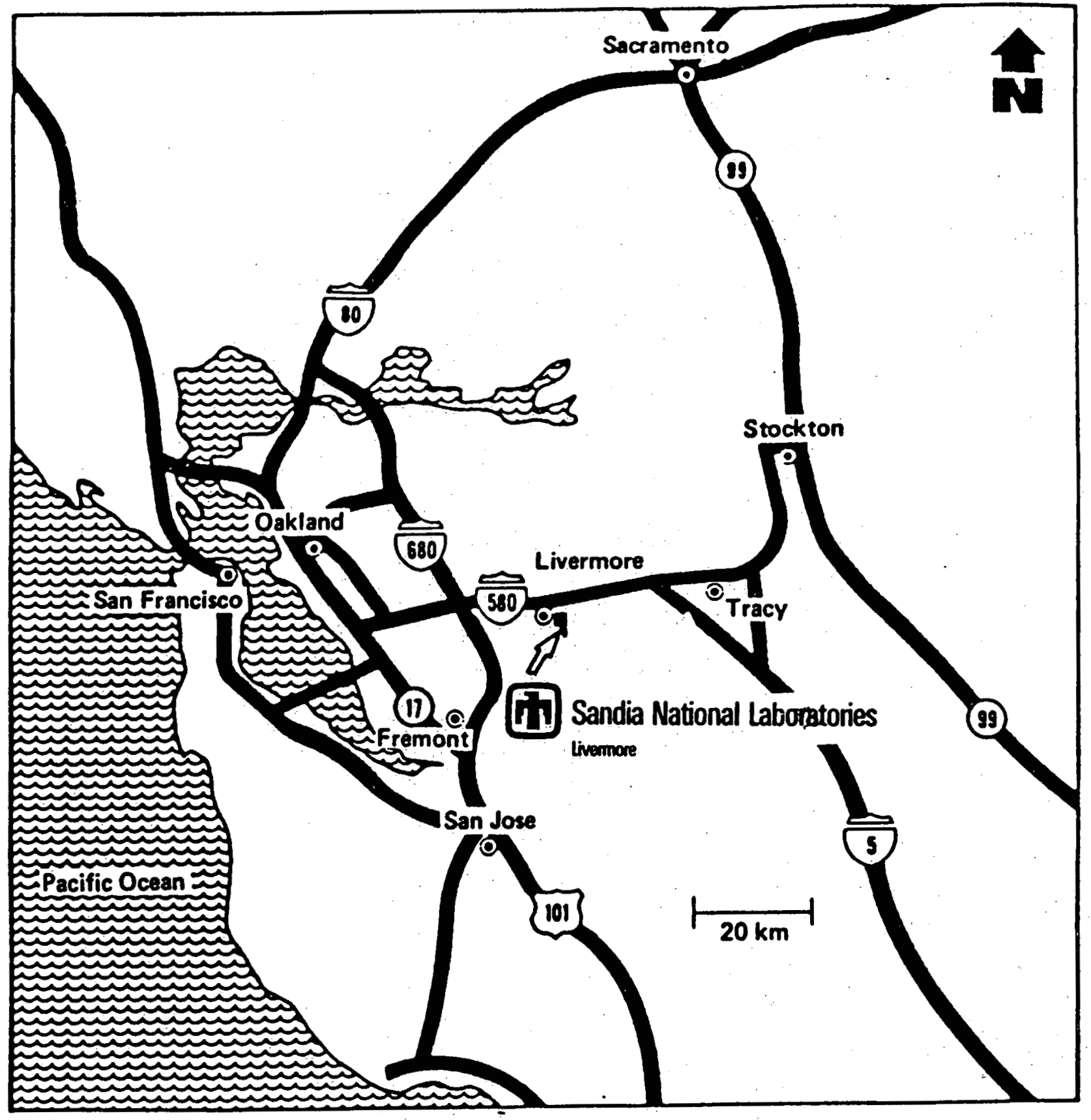

Figure 1. Regional Setting of SNLL 


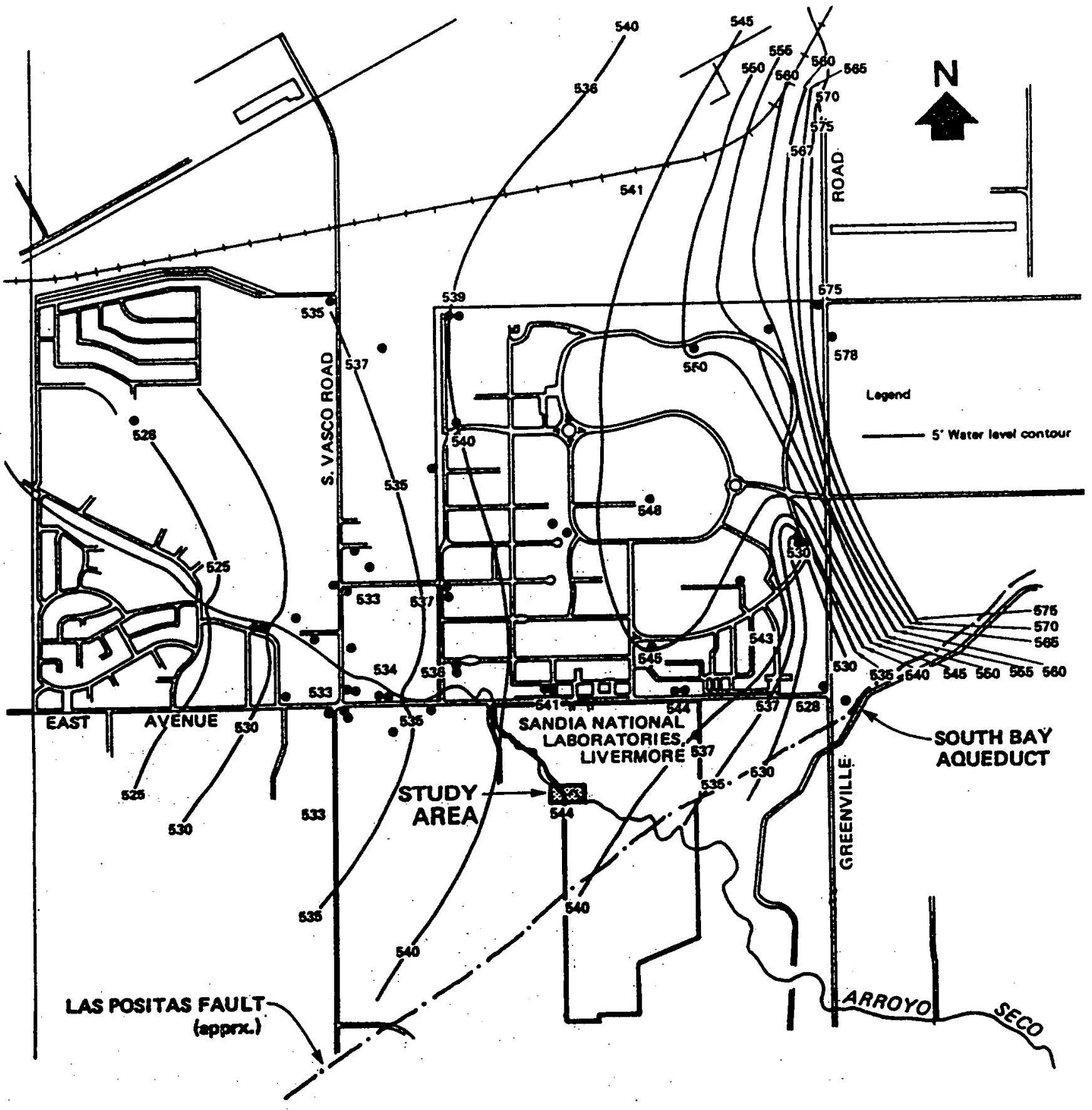

Contour mip provided by Leah Rogers,

Lowrince Livermoro National Leboratories,

Nowember, 1985.

Figure 2. Piezometric Surface - April 1985 


\section{SUMMARY - Environmental Control Program}

SNLL conducts various research activities related to Department of Energy interests. These activities have the potential for release of hazardous materials or radionuclides to the environment. Potential emissions include tritium, depleted uranium, metals, solvents, and common laboratory chemicals. SNLL handles gram quantities of tritium, kilogram quantities of depleted uranium (a by-product of $235 \mathrm{U}$ enrichment - primarily $238 \mathrm{U}$ with approximately $0.2 \% 235 \mathrm{U}$ remaining), but only microcurie quantities of other isotopes. The only radionuclides released during normal operations at SNLL are small amounts of tritium and depleted uranium. Environmental monitoring requirements specific to the Tritium Research Laboratory (TRL) activities were evaluated in 1976 (see Reference 3). A sophisticated monitoring system at the TRL measures operational and atmospheric releases due to tritium research activities (Reference 4). Airborne tritium released in 1986 during research at the TRL was 760 curies (predominantly the oxide form) and 24 millicuries of tritiated water (HTO) was discharged in the liquid effluent. The quantity of depleted uranium released during 1986 was less than 10 microcuries (or 22 grams - analysis near background level) from both liquid and airborne effluents.

Liquid effluent monitoring requirements for hazardous substances were established in 1982 by the Environmental Protection Agency (EPA) National Pretreatment Program provisions of the Clean Water Act. Accordingly, SNLL maintains a strict liquid effluent control program which places maximum emphasis on controlling the effluents at the source. SNLL liquid effluent is monitored at the outfall and discharges directly to the LLNL sewer. The LLNL outfall is again monitored before discharge into the City of Livermore's sanitary sewer system and is processed at the Livermore Water Reclamation Plant. The treated sanitary wastewater is transported out of the Valley and discharged into the San Francisco Bay. During 1986, effluent contaminant levels were below the City of Livermore discharge limits (see Appendix A). continuous liaison is maintained between SNLL and LLNL as to the need for changes in the sampling program and to identify any significant increases in discharge levels.

The Environmental Quality Verification Program conducted by LLNL provides environmental data to evaluate the effectiveness of control measures and to determine any operational impact on the environment. The program employs techniques with sensitivities usually capable of detecting radioactive and nonradioactive pollutants well below applicable standards and environmental background levels. This ensures that the effluent control program is restricting the releases to concentrations below the standards set forth by DOE, EPA, State of California, Alameda County, and the City of Livermore.

The LLNL program includes collection and analysis of air, soil, water, sewer effluent, vegetation, wine, and milk samples. These samples are analyzed for gross alpha and beta radioactivities as well as for specific radionuclides of interest. Environmental background due to penetrating radiation is measured at numerous locations by means of thermoluminescent dosimeters. Complete results of the various environmental evaluations (including error values and ranges) are presented in the LLNL Annual Environmental Monitoring Report (Reference 1) 
and summarized in Tables 1-14. These summary tables include average values of many samples from the last four years to provide a data base for trend analysis.

During 1986, SNLL sought to improve the environmental protection program by initiating various activities. In addition to the liquid effluent control system at the TRL, two additional Liquid Effluent Control System (LECS) designs were initiated. The LECSs are essentially vaulted collection systems to provide hold-up and monitoring capability before release to the sanitary sewer. The Building 910 LECS will service the Printed Wiring Laboratory, and the Building 913 LECS will service electroplating, materials, and chemistry research activities. These systems are expected to be in operation by late 1987. In order to limit releases of tritiated water to the sanitary sewer system to as low as reasonably achievable, design of a low level tritium evaporator was initiated. The system is currently in review by DOE and EPA. Pending EPA approval, the system should be operational by late 1987 .

In the area of ground water protection, a study of the diesel fuel spill was completed and a ground water monitoring plan was developed. Two liquid underground fuel storage tanks with suspect integrity testing results were removed in 1986. Additional hazardous waste storage capability (for waste oil) was installed.

During 1986, SNLL Environmental Protection and Hazardous Waste Management Programs were audited eight times including: the Department of Energy offices in Albuquerque and Washington, DC; the Environmental Protection Agency, Region IX; the California Department of Health Services; the California Regional Water Quality Control Board; the Bay Area Air Quality Management District; and the City of Livermore. These appraisals reflect a high quality SNLL program. 


\section{ENVIRONMENTAL MONITORING PROGRAM}

\section{Atmospheric Pollution}

Concentrations of several airborne contaminants are continuously measured at various locations around the DOE Livermore sites and surrounding valley. The samplers are situated so that a significant release of airborne radioactivity can be detected regardless of local meteorological conditions. Glass and/or cellulose filters are used for particulate collecting media. Gross alpha and beta activity are determined by gas-flow proportional counting; specific alpha and gamma emitters are analyzed using spectrometry techniques; and chemical analysis is used for beryllium determination. The results of particulate radionuclide and beryllium analyses are provided in Tables 1-4. Derived Concentration Guides (DCG) for radioactivity in air and water have been adopted in DOE Order 5480.XX on February 28, 1986 by memo from R. J. Stern to Heads of Field Organizations. The DCG are based on metabolic data and dosimetric models and are used in this report where appropriate. No standards have been provided for gross alpha and gross beta activity in this Order. The data are included in this report for historical continuity.

TABLE 1

Gross Alpha Activity in Air $\left(10^{-15} \mathrm{uCi} / \mathrm{mL}\right)$

\begin{tabular}{lccccc} 
& \multicolumn{3}{c}{ Avg Prior Years } & \multicolumn{2}{c}{1986 Results } \\
LOCATION & 1983 & 1984 & 1985 & Samples & Average \\
\hdashline $\begin{array}{c}\text { Livermore } \\
\text { Site }\end{array}$ & 0.6 & 0.5 & 0.5 & 72 & 0.5 \\
$\begin{array}{c}\text { Livermore } \\
\text { Valley }\end{array}$ & 0.6 & 0.5 & 0.5 & 132 & 0.5 \\
\hline
\end{tabular}

TABLE 2

Gross Beta Activity in Air (10-14 uCi/mL)

\begin{tabular}{lccccc}
\hline & \multicolumn{1}{c}{ Avg Prior Years } & \multicolumn{2}{c}{1986 Results } \\
LOCATION & 1983 & 1984 & 1985 & Samples & Average \\
\hdashline $\begin{array}{c}\text { Livermore } \\
\text { Site }\end{array}$ & 1.0 & 1.1 & 1.4 & 72 & 1.4 \\
$\begin{array}{c}\text { Livermore } \\
\text { Valley }\end{array}$ & 1.4 & 1.5 & 1.9 & 132 & 1.9 \\
\hline
\end{tabular}


TABLE 3

Uranium-238 Concentration in $\operatorname{Air}\left(10^{-5} \mathrm{ug} / \mathrm{m}^{3}\right)$

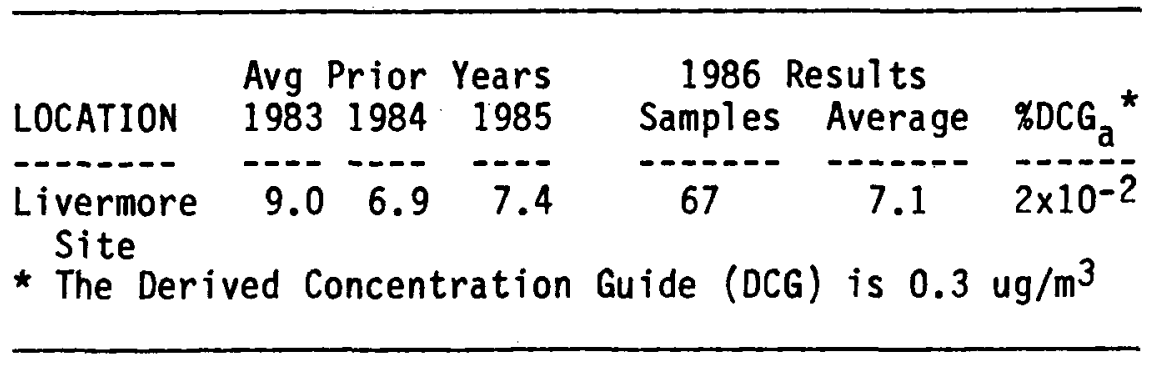

TABLE 4

Beryllium Concentration in $\operatorname{Air}\left(10^{-5} \mathrm{ug} / \mathrm{m}^{3}\right)$

\begin{tabular}{|c|c|c|c|c|c|}
\hline LOCATION & $\begin{array}{l}\text { Avg Prior } \\
19831984\end{array}$ & $\begin{array}{r}\text { Years } \\
1985\end{array}$ & $\begin{array}{c}1986 \\
\text { Samples }\end{array}$ & $\begin{array}{l}\text { Results } \\
s \quad \text { Average }\end{array}$ & $\% C G^{\star}$ \\
\hline $\begin{array}{l}\text { Livermore } \\
\text { Site } \\
\text { *Ambient }\end{array}$ & $2.4 \quad 2.5$ & 6.8 & 72 & 4.2 & 0.4 \\
\hline
\end{tabular}

Each month, half of the perimeter particulate filters are composited for each location and analyzed for beryllium. The concentrations, which are 3 or 4 orders of magnitude below the emission standard, can be accounted for by resuspension of surface soil containing naturally occurring beryllium. Livermore's air typically contains $5 \times 10^{-5} \mathrm{ug} / \mathrm{m}^{3}$ of naturally occurring beryllium.

Water vapor is collected on silica gel samplers at various locations at the LLNL perimeter and analyzed for tritiated water (HTO) concentrations in air. Two additional sampling sites were established during 1977 to provide more precise evaluation of SNLL Tritium Research Laboratory operations. Normal operations at the TRL resulted in 760 curies released up the stack during 1986 as determined by TRL stack monitors. Perimeter airborne levels of HTO are summarized in Table 5.

With the promulgation of the National Emission Standards for Hazardous Air Pollutants (40 CFR 61 , subpart $H$ ), DOE now requires pathway dose calculations using EPA's Clean Air Act Code which conta in the AIRDOS-EPA and RADRISK models. A variety of assumptions and approximations are reflected in the "effective dose equivalents" reported here. The effective dose equivalent attributed to an average perimeter airborne concentration of $1.8 \times 10^{-5} \mathrm{uCi} / \mathrm{mL}$ is calculated to be $0.01 \mathrm{mrem}$. 
TABLE 5

Tritium (HTO) Activity in Air $\left(10^{-5} \mathrm{uCi} / \mathrm{mL}\right)$

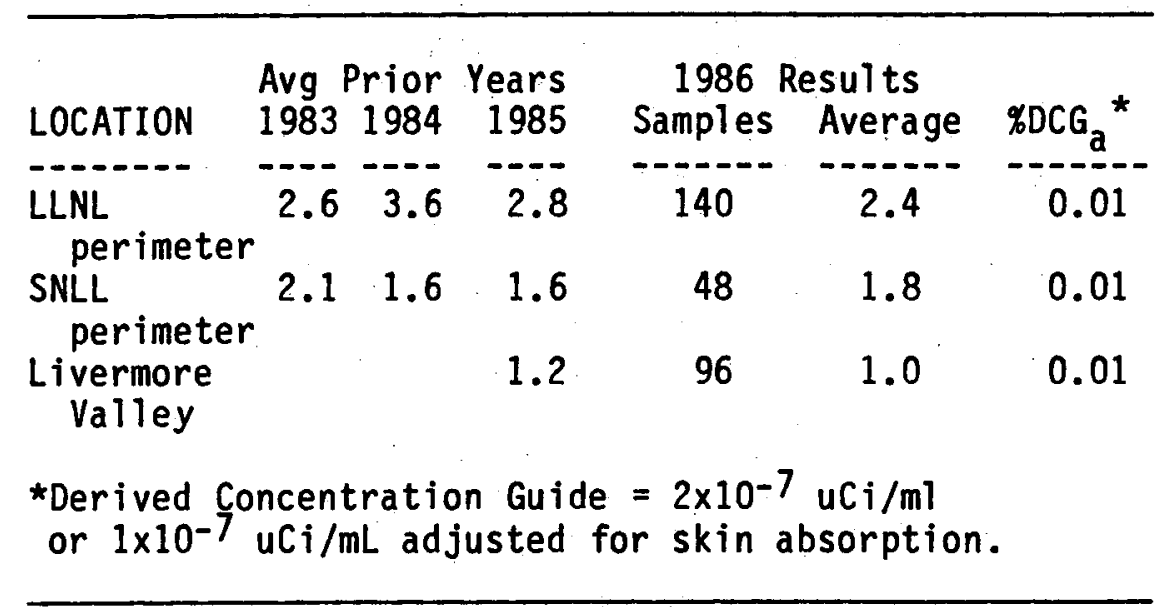

The Bay Area Air Quality Management District (BAAQMD) has issued permits to operate $18 \mathrm{SNLL}$ facilities. Nonradioactive airborne effluents from selected facilities are reported to the BAAQMD on an annual basis. The primary source of nonradioactive airborne pollution is the SNLL steam plant and a small incinerator. The fuels used are natural gas or diesel \#2 and the calculated releases are below applicable guide values (Reference 5).

\section{Soil}

Since 1972, soil sampling has been a part of a continuing surveillance program to document any changes in environmental radioactivity levels. During 1986, 20 locations were sampled and analyzed by radiochemical techniques for $239 \mathrm{Pu}$, $232 \mathrm{Th}, 235 \mathrm{U}, 238 \mathrm{U}$, and naturally occurring $40_{\mathrm{K}}$. Only depleted uranium is handled at SNLL. Soil sampling results for $238 U$ are 1 isted in Table 6 .

Table 6

Uranium-238 in Soil(ug/dry g)

\begin{tabular}{lccccc}
\hline & \multicolumn{2}{c}{ Avg Prior Years } & \multicolumn{2}{c}{1986 Results } \\
LOCATION & 1983 & 1984 & 1985 & Samples & Average \\
\hdashline $\begin{array}{c}\text { Livermore } \\
\text { Valley }\end{array}$ & 2.7 & 2.8 & 4.2 & 23 & 3.7 \\
& & & & &
\end{tabular}


Sewer Effluent

Sewage from SNLL is discharged into the LLNL sewer system which forms a main trunk to the City of Livermore Water Reclamation Plant(LWRP). The SNLL outfall is monitored for $\mathrm{pH}$ and flow on a continuing basis, and composite samples are collected weekly for metals, organics, cyanides, and dissolved solids analysis. Radioactive wastes are collected in hold tanks and sampled near the release point before discharge. LLNL continuously monitors $\mathrm{pH}$, selected metals, and radioactivity at their outfall. At the LWRP, daily samples are collected from the liquid effluent and analyzed for tritiated water. Upon entering the LWRP, main flow is processed by activated sludge technique. Sludge is anearobically digested in two digesters. Methane gas is burned and the remaining sludge is released to large sludge ponds. Reclaimed water is used for irrigation of a nearby golf course, or transported by pipeline to the San Francisco Bay. Releases to the sanitary sewer system are well below standards set forth by DOE and LWRP. Tritium levels in the bay have not changed since the effluent pipeline connection was made in 1980. Table 7 provides results of the LLNL sewer sampling. Table 8 provides the SNLL sampling results which generally meet the City Discharge Limits.

TABLE 7

Tritium (HTO) in Sewage $\left(10^{-3} \mathrm{UCi} / \mathrm{L}\right)$

\begin{tabular}{|c|c|c|c|c|c|}
\hline LOCATION & $\begin{array}{l}\text { Avg Prior } \\
19831984\end{array}$ & $\begin{array}{r}\text { Years } \\
1985\end{array}$ & $\begin{array}{c}1986 \\
\text { Samples }\end{array}$ & $\begin{array}{l}\text { Results } \\
\quad \text { Average }\end{array}$ & $\% D_{C G}^{*}$ \\
\hline $\begin{array}{l}\text { LLNL } \\
\text { Discharge }\end{array}$ & 4.33 .6 & 7.2 & daily & 3.4 & $2 \times 10^{-1}$ \\
\hline LWRP & $0.8 \quad 0.8$ & 1.2 & daily & 0.5 & $2 \times 10^{-2}$ \\
\hline
\end{tabular}


TABLE 8

Physical and Chemical Studies of the SNLL Liquid Effluent

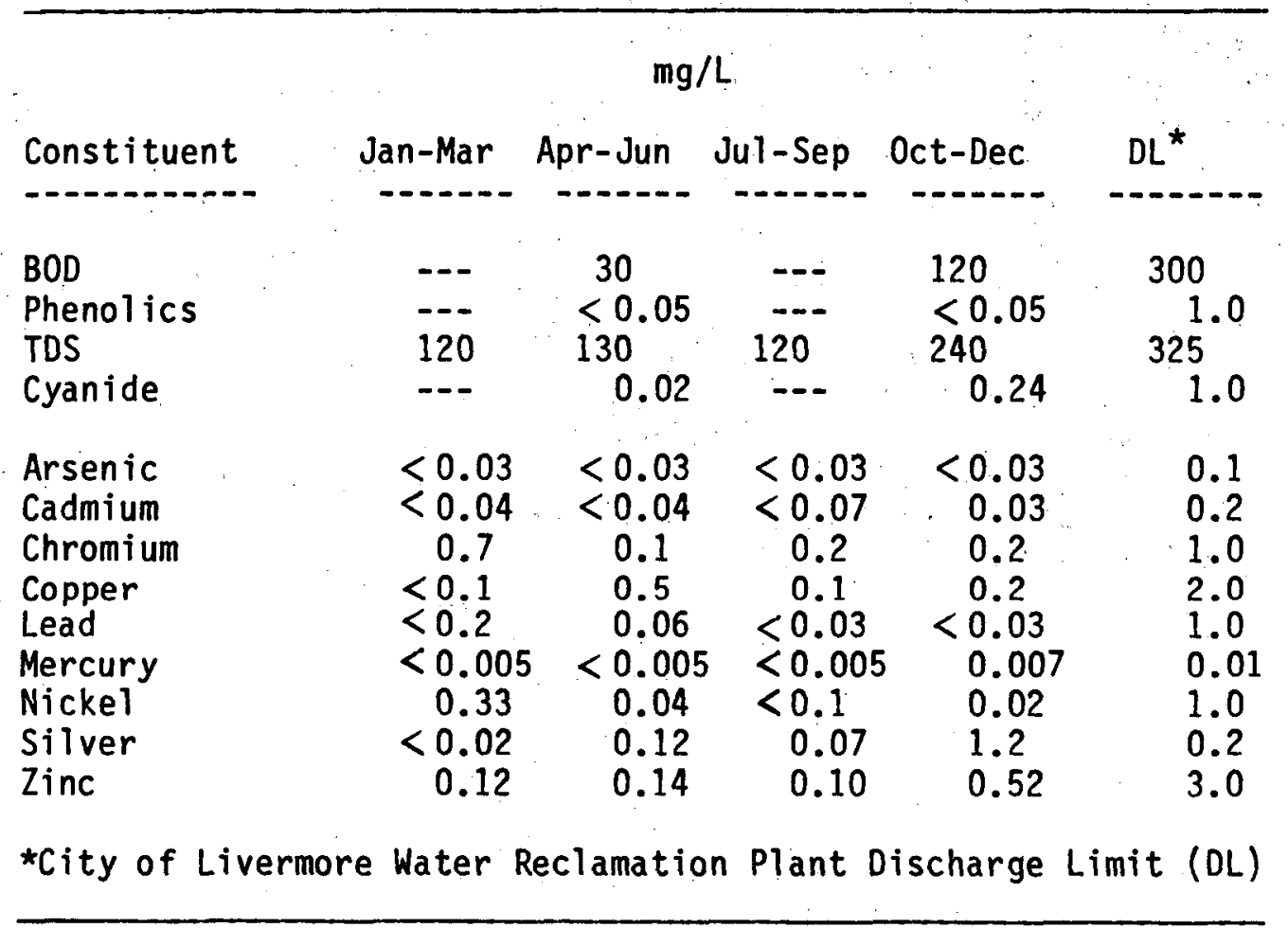

Water Pollution

LLNL collects water samples at various locations in the Livermore Valley to ascertain that radioactivity is not entering the underground water supply. Domestic samples are collected monthly from sources surrounding the Laboratory and extending west to Pleasanton. In addition to the underground water supply, the Zone Seven Aqueduct, which is used for domestic suppiy, is located about $1 / 4$ mile to the east of SNLL. There is also a water treatment plant and storage basin located 2 miles northeast of SNLL.

In 1982 LLNL began a hydrogeologic study to determine the impact of operations on ground water. Analyses were made to determine major cations and anions, dissolved solids, organic carbon, trace organic compounds, gamma emitters and tritium. The results of that study indicated that the local ground water was contaminated with various chiorinated solvents. Since 1983, LLNL and SNLL have been conducting intensive hydrogeochemical investigations. The results of gross alpha, beta, and tritium measurements are provided in Tables 9-11 and indicate that the radioactivity levels are within the EPA and California drinking water standards. Using a standard man assumption of 2 liters/day water intake, an effective dose equivalent calculated for a concentration of $0.9 \mathrm{uCi} / \mathrm{L}$ is $4 \times 10^{-3}$ mrem. 
TABLE 9

Gross Alpha Activity in Livermore Valley Water $(10-9 \mathrm{uCi} / \mathrm{mL})$

\begin{tabular}{lccccc} 
& \multicolumn{3}{c}{ Avg Prior Years } & \multicolumn{2}{c}{1986 Results } \\
LOCATION & 1983 & 1984 & 1985 & Samples & Average \\
\hdashline $\begin{array}{c}\text { Livermore } \\
\text { Valley }\end{array}$ & 2.6 & 2.6 & 3.6 & 48 & 3.1 \\
& & & & &
\end{tabular}

TABLE 10

Gross Beta Activity in Livermore Valley Water $\left(10^{-9} \mathrm{uCi} / \mathrm{mL}\right)$

\begin{tabular}{cccccc} 
& \multicolumn{4}{c}{ Avg Prior Years } & \multicolumn{2}{c}{1986 Results } \\
LOCATION & 1982 & 1983 & 1984 & Samples & Average \\
\hdashline $\begin{array}{c}\text { Livermore } \\
\text { Valley }\end{array}$ & 8.8 & 8.8 & 9.6 & 48 & 10.0 \\
\hline
\end{tabular}

TABLE 11

Tritium (HTO) in Livermore Valley Water $\left(10^{-4} \mathrm{uCi} / \mathrm{L}\right)$

\begin{tabular}{|c|c|c|c|c|}
\hline LOCATION & $\begin{array}{c}\text { Avg Prior Years } \\
1983 \quad 1984 \quad 1985\end{array}$ & Samples & $\begin{array}{l}986 \text { Resu } \\
\text { Average }\end{array}$ & ts $\mathrm{DCG}^{*}$ \\
\hline $\begin{array}{l}\text { Surface Water } \\
\text { Ground Water }\end{array}$ & $\begin{array}{rrr}2.1 & 2.7 & 1.5 \\
3.6 & 3.3 & 2.6\end{array}$ & $\begin{array}{l}58 \\
18\end{array}$ & $\begin{array}{l}0.9 \\
0.5\end{array}$ & $\begin{array}{l}3 \times 10^{-3} \\
2 \times 10^{-3}\end{array}$ \\
\hline
\end{tabular}


In 1975 , as a result of an accidental puncture of an underground transfer 1 ine, $225 \mathrm{~m}^{3}(59,500$ gallons $)$ of \#2 diesel fuel escaped from the $670 \mathrm{~m}^{3}$

(177,000 gallon) reserve fuel tank. SNLL began a short-term ground water investigation in December 1983 to determine the extent of contamination

resulting from the fuel oil spill. Detailed studies indicate that the fuel has slowly moved to the upper aquifer which is not used for either irrigation or drinking water. The plume is being closely monitored by 8 observation wells completed in the vicinity (Figure 4). Details of the spill, the hydrology of the area, and a monitoring report are found in References 6 and 7 . A study of the fuel spill data base was conducted in the fall of 1985 (see Reference 2). Ground water investigations are reported separately (Reference 8 ).

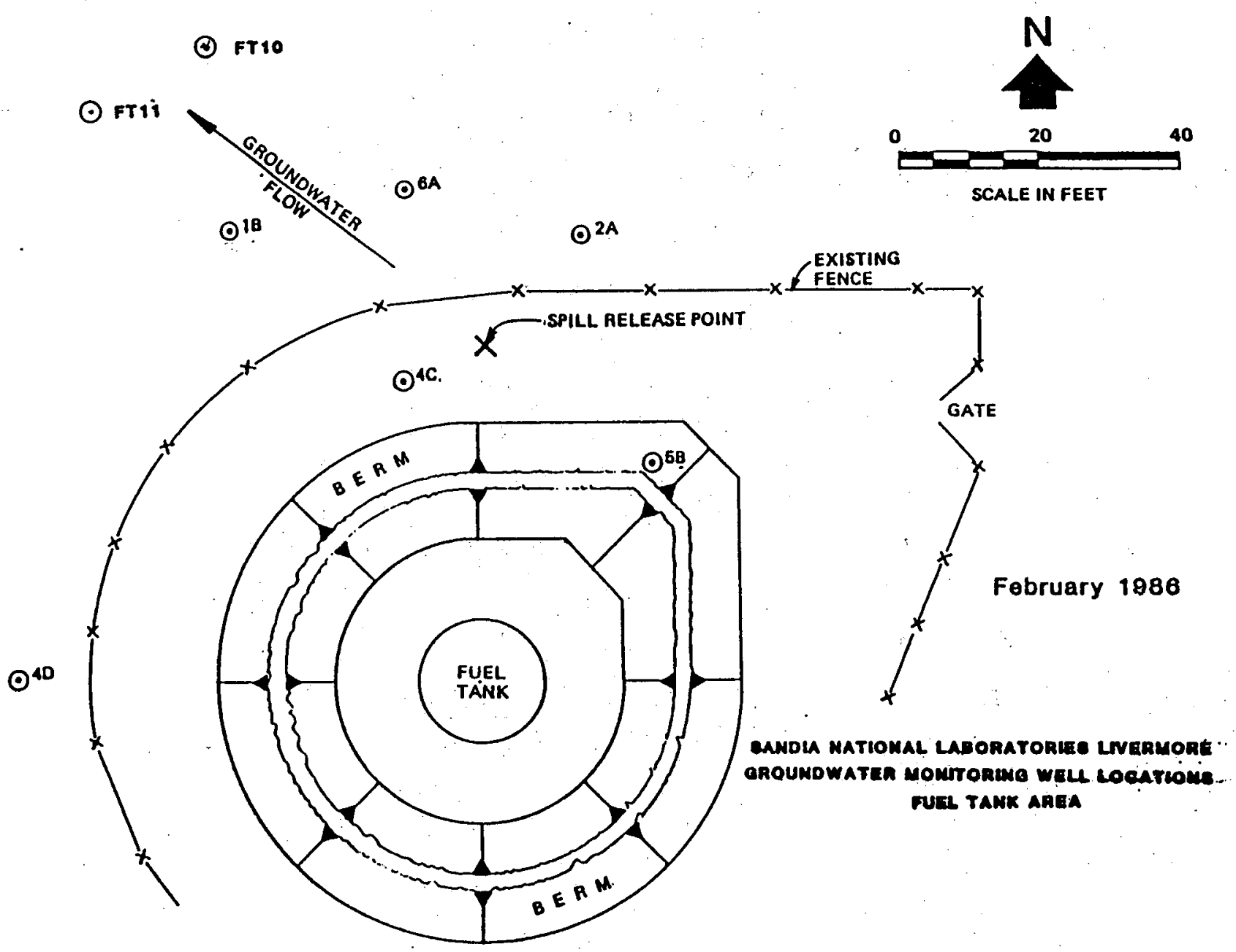

Figure 3. Fuel Spill Evaluation - Location of Wells and Boreholes 


\section{Vegetation and Foodstuffs}

Vegetation samples (usually native grasses) are collected and analyzed for tritium by freeze drying and liquid scintillation counting. LLNL derived effective dose equivalents using accepted dose conversion factors (see Reference 1). For an average vegetation tritium content of $11.8 \times 10^{-4} \mathrm{uCi} / \mathrm{L}$, the effective dose is calculated to be $2 \times 10^{-2} \mathrm{mrem}$. Samples of Livermore Valley wines indicate a somewhat higher level than wines produced from grapes grown outside the valley but within the range found in both European wines and surface waters throughout the world. HTO levels are also measured in honey and goat's milk. The effective dose equivalent of $3.0 \times 10^{-4} \mathrm{uCi} / 1$ tritium in milk is calculated to be $6 \times 10^{-3} \mathrm{mrem}$. Concentrations of tritium in vegetation and foodstuffs are summarized in Table 12.

TABLE 12

Tritium (HTO) in Vegetation and Foodstuffs $\left(10^{-4} \mathrm{uCi} / \mathrm{L}\right)$

\begin{tabular}{lcccccc}
\hline & \multicolumn{2}{c}{ Avg Prior Years } & \multicolumn{2}{c}{1986 Results } \\
LOCATION & 1983 & 1984 & 1985 & Samples & Average \\
\hdashline Vegetation & 10.6 & 14.4 & 35.1 & 32 & 11.8 \\
Wine & 4.2 & 2.4 & 3.4 & 5 & 2.2 \\
Milk & 1.6 & 1.2 & 1.5 & 39 & 3.0 \\
Honey & 7.3 & 4.2 & 4.2 & 2 & 1.8 \\
\hline
\end{tabular}

Thermoluminescent Dosimetry

Background measurements of external penetrating radiation were made at 22 LLNL laboratory perimeter locations. In the Livermore Valley, the median annual background was $62 \mathrm{mrem}$, which is attributable primarily to naturally occurring terrestrial and cosmic background radiation. The average annual LLNL perimeter exposure was $61 \mathrm{mrem}$ which is not a statistically significant difference from background. Table 13 summarizes these measurements. 
TABLE 13

Environmental Radiation Measurements DOE Livermore Site by TLD (mrem)

\begin{tabular}{lcccccc}
\hline & \multicolumn{3}{c}{ Avg Prior Years } & \multicolumn{3}{c}{1986 Results } \\
LOCATION & 1983 & 1984 & 1985 & Samples & Average & Maximum \\
\hdashline LLNL & 51 & 48 & 59 & 88 & 61 & 80 \\
perimeter & & & & & \\
\hline
\end{tabular}

Surface Water Runoff Monitoring

LLNL initiated a pesticide monitoring program in 1975 to analyze surface runoff water samples for pesticides. In 1985, LLNL expanded the analysis to include metals and priority pollutants. During the winter rainy season, water is collected along Arroyo Seco at the east SNLL boundary for the influent measurement and at the west boundary for the effluent sample. Data from Arroyo Seco indicate that most pollutants were not present at detectable levels and the constituents reflect natural variability and flow properties. Selected analyses are presented in Table 14. All other constituents were below the minimum detectable level (Reference 1).

TABLE 14

Storm Water Runoff from Arroyo Seco (mg/L)

\begin{tabular}{lcc}
\hline \multicolumn{1}{c}{ Analyses } & SNLL Influent & SNLL Effluent \\
\hline Arsenic & $<0.001$ & $<0.001$ \\
Barium & $<0.1$ & $<0.1$ \\
Beryllium & $<0.01$ & $<0.01$ \\
Cadmium & $<0.01$ & $<0.01$ \\
Chromium & $<0.02$ & $<0.02$ \\
Lead & $<0.001$ & $<0.001$ \\
Mercury & $<0.0001$ & $<0.0001$ \\
Selenium & $<0.001$ & $<0.001$ \\
Silver & $<0.01$ & $<0.01$ \\
Nitrate & 1.2 & 0.1 \\
Fluoride Ohide & 0.24 & 0.19 \\
Chemical Oxygen Demand (COD) & 110 & 85 \\
Total Organic Carbon (TOC) & 18 & 31 \\
Oil and Grease & 13 & 8 \\
CA Title 22 Organics: & $<0.5$ & 11 \\
2,4 D (ug/L) & & \\
Purgeable Priority Pollutants: & \\
Chloroform (ug/L) & 5 & 3 \\
Trichloroflouromethane (ug/L) & 3 & \\
\hline
\end{tabular}




\section{Solid Wastes}

No solid wastes are disposed of on the SNLL site. Radioactive wastes are shipped to the Nevada Test Site. The disposal of chemical wastes is achieved under contract with local waste handling companies at a Class 1 disposal site in accordance with EPA and California State Regulations (Reference 9).

\section{Quality Assurance}

During 1986, LLNL participated in several intercomparison assessments organized by EPA's Environmental Radioactivity Laboratory and the DOE Environmental Measurements Laboratory. The results were considered satisfactory. Replicate sampling and blank anlysis are part of the Quality Assurance program. These results were considered acceptable reflecting normal sampling, analytical, and natural environmental variations. Reference 1 describes the procedures and results.

During 1986, eight audits and appraisals were conducted by DOE, EPA, and California DHS and RWQCB looking at the SNLL Environmental Protection and Hazardous Waste Management Programs. These regulatory agency audits provide independent review and insure high quality programs at SNLL. 


\section{REFERENCES}

1. R. C. Holland, R. W. Buddemeier, and D. D. Brekke. "Environmental Monitoring at the Lawrence Livermore National Laboratory, 1986 Annual Report", Lawrence Livermore National Laboratory, Livermore, CA, UCRL-50027-86 (1987).

2. Kennedy/Jenks Engineers. "Data Base Evaluation and Fuel Spill Evaluations: Conceptual Monitoring Plan and Future Action Evaluation", Final Report, November 1985.

3. T. K. Devlin. "Preoperational Environmental Monitoring Report for the SNLL Tritium Research Laboratory", SAND76-8033, July 1976.

4. T. K. Devlin. "Tritium Monitoring at the Sandia Tritium Research Laboratory", in IAEA-SM-232/56 (Behavior of Tritium in the Environment) 1979.

5. Bay Area Air Quality Management District. "Rules and Regulations", Latest Update.

6. Hydro Geo Chem. "Subsurface Investigation of Diesel Fuel Spill at the Sandia National Laboratories, Livermore, California", Final Report January 30, 1985.

7. T. K. Devlin. "Ground Water Protection Program Actions and Investigations", Report to the California Regional Water Quality Control Board, April, 1986.

8. T. K. Devlin. "Ground Water Investigations" Status Report to the California Regional Water Qual ity Control Board, December, 1986.

9. "SNLL Hazardous Waste Management Implementation Plan", October 1983 


\section{APPENDIX A}

\section{SUMMARY OF DISCHARGE LIMITS \\ CITY OF LIVERMORE WATER RECLAMATION PLANT}

Section 18.62 of the Code of the City of Livermore states the

discharge limits for the sanitary sewer system. These limits are sumarized:

No discharge of the following:

(a) flammables or explosives (gasoline, benzene, naphtha, fuel oil, etc.)

(b) solid or viscous substance

(c) $\mathrm{pH}$ - outside following limits

(d) toxic pollutants

(e) noxious or malodorous

(f) substances effecting sludge

(g) fat, grease, or oil (freon extractable) $100 \mathrm{mg} / \mathrm{L}$

(h) NPDES violation

(i) objectional color

(j) temperature

6.8 to 8.5

(k) flow rate restritions

(1) radioactive wastes exceeding state or federal limits

(m) hazard to human life or public nuisance

(n) TDS increment chloride increment

(o) B.O.D $325 \mathrm{mg} / \mathrm{L}$ $75 \mathrm{mg} / \mathrm{L}$

(p) suspended solids

300

300

Specfic Pollutant Limitations

$\begin{array}{ll}\text { arsenic } & 0.1 \mathrm{mg} / \mathrm{L} \\ \text { cadmium } & 0.2 \\ \text { copper } & 2.0 \\ \text { cyanide } & 1.0 \\ \text { lead } & 1.0 \\ \text { mercury } & 0.01 \\ \text { nickel } & 1.0 \\ \text { silver } & 0.2 \\ \text { total chromium } & 1.0 \\ \text { zinc } & 3.0 \\ \text { total Cl CHX } & 0.02 \\ \text { phenolics } & 1.0 \\ \text { PCBs } & 0.01\end{array}$


UNLIMITED RELEASE

INITIAL DISTRIBUTION

R. Peterson

Environmental Programs Branch

U. S. Department of Energy

Albuqueque Operations Office

P.0. Box 5400

Al buquerque, NM 87115

G. E. Runkle (30)

Health Protection Branch

$U$. S. Department of Energy

Albuquerque Operations Office

P.0. Box 5400

Albuquerque, NM 87115

L. Dalton

Management Support Division

U. S. Department of Energy

Aibuguerque Operations Office

P.0. Box 5400

Albuquerque, NM 87115

W. D. Burnett, 3310

G. J. Smith, 3314

R. J. Park, 4010

R. S. Claassen, 8000 ; Attn: E. E. Ives, 8100

P. L. Mattern, 8300

R. J. Detry, 8200

R. C. Wayne, 8400

P. E. Brewer, 8260

T. K. Devl in, 8263 (20)

W. V. Ormond III, 8263

W. M. Rego, 8263

K. F. Siegfriedt, 8263

D. A. Wright, 8263

R. D. Cozine, 8410

8263 File EP-51

B. L. Schrader, 8201 (3)

Publications Division, 8265, for OSTI/TIC (30)

Publications Division, 8265/Technical Library Process Division, 3141

Technical Library Process Division, 3141 (3)

P. W. Dean, 8024, for Central Technical Files (3) 